\title{
The Reasons of Apply to the Emergency Department By Priority 3 (Green Tags) Coded Patients and the Effects on the Intensity of the Emergency Department
}

\author{
Erdal Yılmaz
}

Department of Emergency Medicine, University of Health Sciences, Kartal Dr. Lütfi Kırdar City Hospital, İstanbul, Turkey

Submitted: 03.08.2020 Accepted: 03.03.2021

Correspondence: Erdal Yılmaz SBÜ Kartal Dr. Lütfi Kırdar Şehir Hastanesi, Acil Tıp Anabilim Dalı, Istanbul, Turkey E-mail: erdalyilmazmd@gmail.com

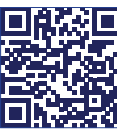

Keywords: Emergency department; green tag; intensity in emergency department; reasons for admission; triage.

This work is licensed under a Creative Commons Attribution-NonCommercial 4 . International License.

\begin{abstract}
Objective: In this study, it is aimed to reach some information that will prepare the ground for the establishment of emergency service database. The urgency and appropriateness of the applications were evaluated for determining the possible rush hours of the emergency department (ED) and planning the workforce; the reasons and times of the inappropriate applications were determined and the measures to be taken to prevent them were discussed.

Methods: This study was prospectively conducted in Ankara Training and Research Hospital, ED. Seven closed-ended questions were asked for the analysis of patients' demographics and 15 closed-ended questions to determine the reasons of ED (green tag) applicant. Data were analyzed using SPSS for Windows vl 8 software and $\mathrm{p}<0.05$ was considered statistically significant.
\end{abstract}

Results: Of the patients, $\mathbf{8 8 . 1 \%}$ had social security. Patients often presented to the ED between 5 PM and 08 AM (52.4\%). Of the patients, $70.2 \%$ stated the reason for not referring to their family physicians within working hours as feeling themselves urgent and willing to have more detailed examination (36.3\%). The leading reason for preferring the ED was its closeness $(36.5 \%)$. It has been determined that all of the patients have referred to the ED at least once in the past year. Patients who came after working hours stated that the reason of their preference for ED because of acute illness (6I.6\%). It was determined that patients preferred ED over family health centers and outpatient clinics for drip-feed (50.6\%) and/or injections (25.4\%).

Conclusion: As a result,we believe that the number of applications can be reduced with the education to be given to individuals, removal of non-urgent procedures from emergency services (injection, dressing, etc.), placement of family health centers in appropriate places, and increasing the trust of the physicians in these centers, increasing the costs of examination contribution from green field patients.

\section{INTRODUCTION}

In recent years, patient intensity is observed in the emergency departments (EDs) because of population growth and internal migrations as well as inadequate use of emergencies, leading to disruptions in health-care services. ${ }^{[1]}$ Admission of ineligible patients in EDs leads to serious problems in the execution of health services. ${ }^{[1-3]}$ Excessive intensity leads to long waiting time for patients, delayed service to the patients in real emergency and serious illness, increased patient dissatisfaction in EDs, increased cost of patient treatment, poor quality of service, serious problems in safety, and low efficiency in personnel working at EDs. ${ }^{[3,4]}$
Patient intensity in EDs may have many causes. Several factors such as the facility of having investigations and receiving treatment at the same day without waiting and accessibility of all specialists at any time of the day play a role in the intend of the inappropriate use of EDs, while this may vary depending on the possibility of access to the health personnel and the perception of the severity of health condition. ${ }^{[5-7]}$ It has been shown that inappropriate admissions of patients to EDs lead to over investigations and treatment. ${ }^{[7]}$

In this study, it was aimed to determine the possible intensive hours in Emergency Medicine Clinic, to have information to plan working hours and workforce, to present the 
emergency and suitability of the admissions, and to put forward precautions to be taken.

\section{MATERIALS AND METHODS}

This study was prospectively conducted after receiving approval from the local ethics committee of the hospital. The study was performed with 1000 green tag coded patients over the age of 18 who admitted to adult ED of Ankara Training and Research Hospital and agreed to participate in the study.

Trauma cases, patients hospitalized after green tag examination, patients who underwent interventions, cases under observation, cases referred to another health service provider or those brought from another health service provider through 112 ambulance services, foreign patients, and those aged under 18 years were excluded from the study. Survey results of 37 persons who were identified to be under I8yearsold, 24 persons who were found to be foreign nationals, and 42 persons who refused to answer the questionnaire were ignored and the questionnaire was completed by 103 patients again.

Seven closed-ended questions were asked to the patients included in the study for the analysis of demographics (age, gender, educational status, employment status, oc- cupation, social security, and ED admission time). Fifteenclosed-ended questions were asked to identify the causes of ED referrals.

\section{Statistical analysis}

The data were analyzed using SPSS for Windows version 18 software. Median and frequency values were used in the descriptive statistics of the data. The distribution of the variables was checked through the KolmogorovSmirnov test. The interquartile range (IQR) was used to show the distribution. Mann-Whitney $U$ and KruskalWallis test were used in the analysis of numerical nonparametric data, and the analysis of non-numerical data was performed with Chi-square and Fisher's exact Chisquare test. $P<0.05$ wasconsidered statistically significant.

\section{RESULTS}

The total number of patient referrals to the hospital was 199,204 persons at the date of the study. Of these patients, I I 5,420 (76\%) were examined in outpatient clinics and 48,284 (24\%) in the ED. Among the patients examined in the ED, 690 (1.4\%) were red tag coded, 25,25I (52.3\%) yellow tag coded, and 22,343 (46.3\%) green tag coded patients.

Table I. The relationship between the reasons for patients to prefer emergency department and age, gender, educational level, employment status, social security, and time of admission

\begin{tabular}{|c|c|c|c|c|c|}
\hline & \multicolumn{5}{|c|}{ The reason of preferring our ED } \\
\hline & $\begin{array}{l}\text { Closeness } \\
(n=365)\end{array}$ & $\begin{array}{l}\text { Easy transportation } \\
\qquad(n=346)\end{array}$ & $\begin{array}{l}\text { Liking the hospital } \\
\qquad(n=\mid 37)\end{array}$ & $\begin{array}{l}\text { Trust in the doctor } \\
\qquad(n=152)\end{array}$ & $\mathbf{p}$ \\
\hline Age, median (min-max) & $37(18-77)$ & $37(18-76)$ & $37(18-80)$ & $37.5(19-73)$ & 0.996 \\
\hline \multicolumn{6}{|l|}{ Gender, n (\%) } \\
\hline Male & $211(57.8)$ & I6I (46.5) & $69(50.4)$ & 71 (46.7) & 0.014 \\
\hline Female & $154(42.2)$ & $185(53.5)$ & $68(49.6)$ & $81(53.3)$ & \\
\hline \multicolumn{6}{|l|}{ Education, n (\%) } \\
\hline Illiterate & $12(3.3)$ & $10(2.9)$ & $6(4.4)$ & $7(4.6)$ & 0.109 \\
\hline Literate & $5(1.4)$ & $8(2.3)$ & $2(1.5)$ & $6(3.9)$ & \\
\hline Primary school & $134(36.7)$ & $108(3 \mid .2)$ & $47(34.3)$ & $54(35.5)$ & \\
\hline High school & $132(35.8)$ & $104(30.4)$ & $50(35.1)$ & $55(35.9)$ & \\
\hline College & $79(21.6)$ & 114 (32.9) & $31(22.6)$ & $29(19.1)$ & \\
\hline Master's degree & $3(0.8)$ & $2(0.6)$ & I (0.7) & I (0.7) & \\
\hline \multicolumn{6}{|l|}{ Employment, n (\%) } \\
\hline Unemployed & $81(22.2)$ & $76(22.0)$ & $35(25.5)$ & $43(28.3)$ & 0.670 \\
\hline Employed & $204(55.9)$ & $187(54.0)$ & $73(53.3)$ & $74(48.7)$ & \\
\hline Student & $30(8.2)$ & $41(11.8)$ & II (8.0) & $16(10.5)$ & \\
\hline Retired & $50(13.7)$ & $42(12.1)$ & $18(13.1)$ & $19(12.5)$ & \\
\hline \multicolumn{6}{|l|}{ Social security, n (\%) } \\
\hline Yes & $327(89.6)$ & 307 (88.7) & II $8(86.1)$ & $129(84.9)$ & 0.404 \\
\hline No & $38(10.4)$ & $39(11.3)$ & $19(13.9)$ & $23(15.1)$ & \\
\hline \multicolumn{6}{|l|}{ Time of admission, $n(\%)$} \\
\hline $0800-1700$ & $173(47.4)$ & $179(5 \mid .7)$ & $61(44.5)$ & $63(41.4)$ & 0.158 \\
\hline $1700-0800$ & $192(52.6)$ & $167(48.3)$ & $76(55.5)$ & $89(58.6)$ & \\
\hline
\end{tabular}


The median age of the 1000 patients admitted to the study was found as 37 (IQR: 20) (I8-80). Of the patients, 512 (51.2\%) were male and $488(48.8 \%)$ female. Of the patients, 35 (3.5\%) were illiterate, 2I (2.1\%) literate, 343 (34.3\%) graduated from primary school, 34 I (34.1\%) high school, 253 (25.3\%) college, and 7 (0.7\%) graduated from a master's degree. Of the participants, 235 (23.5\%) were unemployed, 538 (53.8\%) employed, 98 (9.8\%) were students,and 129 (12.9\%) were retired. Of the patients included in the study, $172(32.0 \%)$ were workers/servants, 169 (3I.1\%) tradesman/self-employed, 22 (4.I\%) soldier/ police/guard/security, $52(9.7 \%)$ teachers, $49(9.1 \%)$ officers, 32 (5.9\%) doctors/EMT/ pharmacists/biologists, 17 (3.2\%) computing staff/banker/secretary, II (2.0\%) engineers, 6 (I.1\%) accountants, 5 (0.9\%) lawyers/prosecutors, $4(0.7 \%)$ farmers, and I patient was journalist. Of the patients, 881 ( $88.1 \%)$ had social security, while 119 (I2\%) had no social security.

Of the patients, 476 (47.6\%) presented to the ED between 08:00 and 17:00 and 524 (52.4\%) between 17:00 and 08:00. As education level increased, the rate of recognition family physician increased significantly $(p<0.05)$. The incidence of knowing family physician was significantly higher among the patients with social security $(p<0.05)$. Of the participants, $744(74.4 \%)$ have previously been examined by their family physician and the rate of examination by family physicians was found to be significantly higher in the patients with social security $(p<0.05)$.

Of the patients included in the study, $482(48.2 \%)$ stated that they had previously used 112 ambulance services. The age of patients who had previously called 112 was significantly higher $(p<0.05)$. Whereas the rate of previously calling 112 was lower among the students, this rate was found to be significantly higher among the retired persons $(p<0.05)$. Of the participants, $702(70.2 \%)$ reported that they felt themselves urgent. Age of patients who felt themselves urgent was significantly higher $(p<0.05)$. Illiterate, primary school, and college graduates were found to feel themselves in emergency more frequently $(p<0.05)$. Again, patients without social security were also found to more often feel themselves urgent $(p<0.05)$.

When the patients participating in the study were questioned about why do not choose to be examined by the family physician during working hours, 128 (26.9\%) stated that the family health center was remote, $102(21.4 \%)$ did not trust in family physicians, $173(36.3 \%)$ wished to have more detailed examination, and 73 (15.3\%) did not go to family physician due to other reasons.

When the patients were questioned about the reasons for choosing our ED patients,365 (36.5\%) of the patients

Table 2. The relationship between the incidence of patients' referral to emergency department within the past I year and age, gender, educational level, employment status, social security, and time of admission

\begin{tabular}{|c|c|c|c|c|c|}
\hline & \multicolumn{5}{|c|}{ Number of admissions to ED within thepast I year } \\
\hline & $\begin{array}{c}\mathrm{I}-2 \\
(n=456)\end{array}$ & $\begin{array}{c}3-5 \\
(n=335)\end{array}$ & $\begin{array}{c}6-10 \\
(n=134)\end{array}$ & $\begin{array}{c}10+ \\
(n=75)\end{array}$ & $\mathbf{p}$ \\
\hline Age, median (min-max) & $37(18-76)$ & $36(18-76)$ & $37(19-76)$ & $37(18-80)$ & 0.831 \\
\hline \multicolumn{6}{|l|}{ Gender, n (\%) } \\
\hline Male & $236(51.8)$ & $180(53.7)$ & $67(50.0)$ & $29(38.7)$ & 0.127 \\
\hline Female & $220(48.2)$ & $155(46.3)$ & $67(50.0)$ & $46(61.3)$ & \\
\hline \multicolumn{6}{|l|}{ Education } \\
\hline Illiterate & II (2.4) & $13(3.9)$ & $5(3.7)$ & $6(8.0)$ & 0.080 \\
\hline Literate & $10(2.2)$ & $4(1.2)$ & $3(2.2)$ & $4(5.3)$ & \\
\hline Primary school & $163(35.7)$ & $113(33.7)$ & $4 \mathrm{I}(30.6)$ & $26(34.7)$ & \\
\hline High school & $157(34.4)$ & $103(30.7)$ & $59(44.0)$ & $22(29.3)$ & \\
\hline College & $112(24.6)$ & $99(29.6)$ & $25(18.7)$ & $17(22.7)$ & \\
\hline Master's degree & $3(0.7)$ & $3(0.9)$ & I (0.7) & 0 & \\
\hline \multicolumn{6}{|l|}{ Employment, n (\%) } \\
\hline Unemployed & $97(21.3)$ & $79(23.6)$ & $38(28.4)$ & $21(28.0)$ & 0.103 \\
\hline Employed & $259(56.8)$ & $179(53.4)$ & $66(49.3)$ & $34(45.3)$ & \\
\hline Student & $53(\mathrm{II} .6)$ & $30(9.0)$ & $10(7.5)$ & $5(6.7)$ & \\
\hline Retired & $47(10.3)$ & $47(14.0)$ & $20(14.9)$ & $15(20.0)$ & \\
\hline \multicolumn{6}{|l|}{ Social security, n (\%) } \\
\hline Yes & $4 I I(90.1)$ & $293(87.5)$ & II 4 (85.I) & $63(84.0)$ & 0.231 \\
\hline No & 45 (9.9) & $42(12.5)$ & $20(14.9)$ & $12(16.0)$ & \\
\hline \multicolumn{6}{|l|}{ Time of admission, $n$ (\%) } \\
\hline $0800-1700$ & $223(48.9)$ & $159(47.5)$ & $56(41.8)$ & $38(50.7)$ & 0.492 \\
\hline $1700-0800$ & $233(51.1)$ & $176(52.5)$ & $78(58.2)$ & $37(49.3)$ & \\
\hline
\end{tabular}


stated that they preferred this ED because it was close to them. While male patients chosen the ED because its closeness, female patients were found to often refer to our ED because of easy transportation $(p<0.05)$ (Table I).

It was determined that $456(45.6 \%)$ of the participants referred to ED I-2 times, 335(33.5\%) 3-5 times, I34 (13.4\%) 6-10 times, and 75 (7.5\%) more than 10 times within the past lyear. No statistically significant correlation was found between the incidence of admission to ED and age, gender, educational level, employment status, social security, and time of admission ( $p>0.05$ ) (Table 2$)$.

It was found that incidence of admission was more than 10 in illiterate, only literate, and primary school graduated persons, while the frequency of referral to ED was relatively lower among high school, college, and master's degree graduated patients $(p<0.05)$. The rate of admission to outpatient clinics washigher among unemployed and retired persons, while this incidence was relatively lower in the employed persons and students $(p<0.05)$.

Of the patients included in the study, 270 (27.0\%) reported that they could wait for $30 \mathrm{~min}$ and 189 (18.9\%) for $60 \mathrm{~min}$, while $310(31.0 \%)$ patients stated that they could wait until end of the order, but 23I (23.I\%) patients stated that they did not want to wait (Table 3).
It was determined that 254 (25.4\%) of the patients participating in the study thought that priority was themselves, and $746(74.6 \%)$ had the opinion that priority was of the other patients. The demand of primary school graduates to be examined according to the order of application was found to be remarkable $(p<0.05)$. Of the patients included in the study, 745 (74.5\%) advocated that examinations should be carried out according to the triage system, while 255 (25.5\%) patients did not accept this opinion. There was no statistically significant correlation between determination of the order of examination according to triage system and age and gender, employment status, social security, and time of admission ( $p>0.05)$.

It was learned that, among the patients who were asked why they preferred to refer to the ED after working hours, 323 (61.6\%) reported that they newly got sick, 90 (17.2\%) stated that they could not come in the daytime because of working hours, 79 (15.1\%) because of their jobs, and $32(6.1 \%)$ reported that they had no any relative to bring $\mathrm{him} /$ her. Admission of the employed persons to ED out of working hours was significantly higher $(p<0.05)$. When the reasons for presenting to ED were examined even outpatient clinics were open, it was found that 222 (46.6\%) patients referred to the ED with the opinion of their condition wereurgent, 105 (22.1\%) because of long waiting

Table 3. The relationship between time the patients can wait in emergency department and age, gender, educational level, employment status, social security, and time of admission

\begin{tabular}{|c|c|c|c|c|c|}
\hline & \multicolumn{5}{|c|}{ Time the patients can wait } \\
\hline & $\begin{array}{c}30 \text { min } \\
(n=270)\end{array}$ & $\begin{array}{l}60 \min \\
(n=189)\end{array}$ & $\begin{array}{l}\text { End of order } \\
\qquad(n=3 \mid 0)\end{array}$ & $\begin{array}{c}\text { Cannot wait } \\
(n=231)\end{array}$ & $\mathbf{p}$ \\
\hline Age, median (min-max) & $37(18-76)$ & $35(19-80)$ & $37(18-72)$ & $38(18-76)$ & 0.111 \\
\hline \multicolumn{6}{|l|}{ Gender, n (\%) } \\
\hline Male & $142(52.6)$ & $104(55.0)$ & $159(51.3)$ & $107(46.3)$ & 0.318 \\
\hline Female & $128(47.4)$ & $85(45.0)$ & I5I (48.7) & $124(53.7)$ & \\
\hline \multicolumn{6}{|l|}{ Education, n (\%) } \\
\hline Illiterate & $5(1.9)$ & $10(5.3)$ & $10(3.2)$ & $10(4.3)$ & 0.321 \\
\hline Literate & $6(2.2)$ & $2(I . I)$ & $9(2.9)$ & $4(1.7)$ & \\
\hline Primary school & $84(31.1)$ & $61(32.3)$ & $109(35.2)$ & $89(38.5)$ & \\
\hline High school & $96(35.6)$ & $71(37.6)$ & 105 (33.9) & $69(29.9)$ & \\
\hline \multicolumn{6}{|l|}{ Employment, n (\%) } \\
\hline College & 78 (28.9) & $43(22.8)$ & $73(23.5)$ & $59(25.5)$ & 0.021 \\
\hline Master's degree & I (0.4) & $2(1.1)$ & $4(1.3)$ & 0 & \\
\hline Unemployed & $61(22.6)$ & $33(17.5)$ & $78(25.2)$ & $63(27.3)$ & \\
\hline Employed & I 48 (54.8) & $106(56.1)$ & $173(55.8)$ & III (48.I) & \\
\hline Student & $29(10.7)$ & $24(12.7)$ & $30(9.7)$ & $15(6.5)$ & \\
\hline Retired & 32 (1 1.9) & $26(13.8)$ & $29(9.4)$ & $42(18.2)$ & \\
\hline \multicolumn{6}{|l|}{ Social security, n (\%) } \\
\hline Yes & $238(88.1)$ & $167(88.4)$ & $274(88.4)$ & $202(87.4)$ & 0.988 \\
\hline No & $32(11.9)$ & $22(11.6)$ & $36(11.6)$ & $29(12.6)$ & \\
\hline \multicolumn{6}{|l|}{ Time of admission, $\mathrm{n}(\%)$} \\
\hline $0800-1700$ & $134(49.6)$ & 74 (39.2) & $160(51.6)$ & $108(46.8)$ & 0.048 \\
\hline $1700-0800$ & $136(50.4)$ & $115(60.8)$ & $150(48.4)$ & $123(53.2)$ & \\
\hline
\end{tabular}


Table 4. The relation between patients' preference of emergency departments over outpatient clinics and family health centers, and age, gender, educational level, employment status, social security, and time of admission

\begin{tabular}{|c|c|c|c|c|c|}
\hline & \multicolumn{5}{|c|}{ Preference of ED over polyclinics and family health centers } \\
\hline & $\begin{array}{l}\text { Injection } \\
(n=254)\end{array}$ & $\begin{array}{l}\text { Drip-feed } \\
(n=506)\end{array}$ & $\begin{array}{l}\text { Examination } \\
(n=142)\end{array}$ & $\begin{array}{l}\text { Investigation } \\
\quad(n=98)\end{array}$ & $\mathbf{p}$ \\
\hline Age, median (min-max) & $36(18-75)$ & $38(18-77)$ & $36(18-76)$ & $37.5(19-80)$ & 0.092 \\
\hline \multicolumn{6}{|l|}{ Gender, n (\%) } \\
\hline Male & $109(51.9)$ & $119(50.0)$ & $149(49.0)$ & $135(54.4)$ & 0.615 \\
\hline Female & $101(48.1)$ & $119(50.0)$ & I55 (5I.0) & $113(45.6)$ & \\
\hline \multicolumn{6}{|l|}{ Education, $\mathrm{n}(\%)$} \\
\hline Illiterate & $8(3.8)$ & $6(2.5)$ & $9(3.0)$ & $12(4.8)$ & 0.382 \\
\hline Literate & $4(1.9)$ & $6(2.5)$ & $6(2.0)$ & $5(2.0)$ & \\
\hline Primary school & $66(31.4)$ & $80(33.6)$ & $99(32.6)$ & $98(39.5)$ & \\
\hline High school & $82(39.0)$ & $90(37.8)$ & $98(32.2)$ & 7I (28.6) & \\
\hline College & $50(23.8)$ & $55(23.1)$ & $88(28.9)$ & $60(24.2)$ & \\
\hline Master's degree & 0 & I (0.4) & $4(1.3)$ & $2(0.8)$ & \\
\hline \multicolumn{6}{|l|}{ Employment, n (\%) } \\
\hline Unemployed & 48 (22.9) & $47(19.7)$ & $73(24.0)$ & $67(27.0)$ & 0.420 \\
\hline Employed & $115(54.8)$ & $135(56.7)$ & I55 (5I.0) & $133(53.6)$ & \\
\hline Student & $23(11.0)$ & $20(8.4)$ & $37(12.2)$ & $18(7.3)$ & \\
\hline Retired & $24(11.4)$ & $36(15.1)$ & $39(12.8)$ & $30(12.1)$ & \\
\hline \multicolumn{6}{|l|}{ Social security, n (\%) } \\
\hline Yes & I88 (89.5) & $215(90.3)$ & $266(87.5)$ & $212(85.5)$ & 0.353 \\
\hline No & $22(10.5)$ & $23(9.7)$ & $38(12.5)$ & $36(14.5)$ & \\
\hline \multicolumn{6}{|l|}{ Time of admission } \\
\hline $0800-1700$ & $107(51.0)$ & $105(44.1)$ & $140(46.1)$ & $124(50.0)$ & 0.397 \\
\hline $1700-0800$ & $103(49.0)$ & $133(55.9)$ & $164(53.9)$ & $124(50.0)$ & \\
\hline
\end{tabular}

lines in polyclinics, 86 (18.1\%) failure to have appointment or order, and 63 (13.2\%) due to long procedures in outpatient clinics.

When patients included in the study were questioned about why they preferred ED over family health centers and outpatient clinics, it was found that 254 (25.4\%) referred to the ED for having an injection, 506 (50.6\%) for having drip-feed, 142 (14.2\%) only for having examination, and $98(9.8 \%)$ for having investigations (Table 4$)$.

\section{DISCUSSION}

Because of the patients presented to ED although they have no emergency, waiting time in EDs is extended, the cost of the EDs is increased, the staff is unnecessarily overloaded and the chaos environment occurs if the necessary precautions have not been taken. ${ }^{[8]}$

As in the whole world, non-emergency patients seem to frequently present to EDs, causing disruption in the service. ${ }^{[2]}$ Studies have shown that non-emergency admissions are accounted for 14-85\% of ED referrals. ${ }^{[9]}$ In our country, Çevik and Tekir ${ }^{[10]}$ reported that $24 \%$ of the patients and Kılıçaslan et al. ${ }^{\left[{ }^{\prime \prime}\right]}$ reported that $47 \%$ of the patients were non-emergency green tag coded patients. In our study, $46 \%$ of the patients who admitted to the ED of our hospital were accepted as green tag coded patients. Of the total number of hospital admissions, II.1\% are green tag coded patients, which is a quite high rate. In our study, the rate of patients who are seen in the green tag is in line with the literature. It was found that the number of patients who think themselves in emergency despite they were green tag coded was considerably high (70.2\%). Raising awareness about emergency diseases is needed in non-emergency patients.

In a study by Northington et al., ${ }^{[12]}$ the mean age of non-emergency patients was found as 36 and this mean age was similar to that of emergency patients. Similar to the literature, in our study, the mean age of the patients who referred to ED was found as 37 years. Northington et al. ${ }^{[12]}$ reported that $53 \%$ of non-emergency patients were male and no correlation was observed between gender and urgency status. Consistently with the literature, in the present study, $51.2 \%$ of the patients presented to ED were male.

Morrison et al. ${ }^{[13]}$ reported that individuals with low educational levels refer more to EDs (green tag area). It was determined that primary school and high school graduates were predominant in our study. In a study by Gentile et al., ${ }^{[14]} 59 \%$ of non-emergency patients were employed. In our study, $53.8 \%$ of the persons referred to ED were em- 
ployed. We think that an employee who could not get off during the day or who has a limited period of time may apply to ED after the working hours because outpatient clinics are closed at that time.

In the study conducted by Öztürk, ${ }^{[15]}$ it has been reported that the patients were the most frequent come among workers followed by self-employed persons. In our study, it was determined that the most frequent admission to ED was made by servant/worker group followed by trades$\mathrm{men} / \mathrm{self}$-employed people. In their study, Sun et al. ${ }^{[6]}$ stated that patients preferred EDs to receive free medical care. In their study, Northington et al. ${ }^{[12]}$ noted that patients have an interest such as free care in admission to ED. Öztürk ${ }^{[15]}$ reported that $92.5 \%$ and Çevik and Tekir stated that $97 \%$ of the patients had social security. In our study, $88.1 \%$ of patients had social security.

In their study, Tsai et al. ${ }^{\left[{ }^{[17]}\right.}$ found that non-emergency patients refer to ED between 08:00 and 18:00. Afilalo et al. ${ }^{[18]}$ stated that real emergency patients came to ED more often at night. In our study, it was found that $52.4 \%$ of the patients presented to ED between 17:00 and 08:00 $\mathrm{h}$. Weisz et al. ${ }^{[19]}$ reported that $30 \%$ of the patients were not registered with primary care health service (PCHS). Philips et al. ${ }^{[20]}$ compared PCHS and ED examinations and found that patients presenting to ED had a lower PCHS registration, while those registered with PCHS had social security at a higher rate. In their study, Çetinkaya et al. ${ }^{[2]}$ reported that $15 \%$ of the individuals did not know their family physician; rate of home visits by family physician was $12.4 \%$ and that the individuals could not fully adapted to the family physician system. In our study, we found that $25.3 \%$ of the patients did not know their family physicians and the rate of recognition of the family physicians increased as the educational level increased and in the presence of social security. It was determined that $74.4 \%$ of the patients participating in the study had previously been examined by the family physician and the rate of examination by family physician was higher among the patients who had social security. It has been determined that one-fourth of the patients never visited their family physicians before. It is thought that family physicians need field work in this regard. There was no evidence in the literature about how often the green tag coded patients used ambulance service before. However, Niska et al. ${ }^{[22]}$ reported that $15.5 \%$ of the patients were brought by ambulance. In the present study, we found that $48.2 \%$ of the patients who included in the study had already used I I 2 services and this usage was higher in elderly and retired patients. Başol et al. ${ }^{[23]}$ stated that patients were not expected to wait for treatment even if they had an appointment in the outpatient clinic. In their study, Haddy et al. ${ }^{[24]}$ noted that non-emergency patients expressed their condition as an acute pathology to be intervened immediately.

It was found that $70.2 \%$ of the patients included in our study felt themselves in emergency and these patients were relatively older with lower education level and without social security. In a study by Sempere-Selva et al., ${ }^{[25]}$ it was argued that the admission that in fact should be made to PCHSs isresulted from the lack of confidence in these departments. In their study, Alagöz et al. ${ }^{[26]}$ reported that $67 \%$ of the patients thought that family physicians were inadequate. In their study, Çetinkaya et al. ${ }^{[2]]}$ reported that although patients thought that access to physician is facilitated, they primarily use hospital by 50.3 in the case of any health problem. In their study, Başol et al. ${ }^{[23]}$ stated that patients preferred the big hospital even for an injection because of the concern about side effects that could develop. It has been determined that the reasons of patients included in this study for not using the family physician during working hours were the desire to have more detailed examination followed by distance and confidence in family physician. In the study by Philips et al., ${ }^{[20]}$ the most important first reason for non-emergency patients' preference for ED was stated as accessibility, and the second reason was closeness. In a study by Afilalo et al.,, ${ }^{[18]}$ accessibility $(32.1 \%)$ and need $(22.1 \%)$ were the most frequent causes of ED referral among non-emergency patients. Weisz et al. ${ }^{\left[{ }^{[9]}\right]}$ reported that $46 \%$ of the patients came to ED because of its closeness. ${ }^{[19]}$ In their study, Al et al. ${ }^{[2]}$ stated the leading reason for ED referral was the distance. In our study, we found that the most frequent reason for choosing ED was close distance (34.6\%), while this reason was closeness among the male and easy transportation among female patients. In their study, Philips et al. ${ }^{[20]}$ found that patients used ED by $40 \%$ over the past year.

In their study, Çevik and Tekir ${ }^{[10]}$ reported the rate of patients' repetitive admission to ED as $44 \%$. According to 2013 data of Turkey, the frequency of admission to ED is around 1.2 per person. ${ }^{[28]}$ In our study, it has been determined that all of the patients enrolled in the study have referred to ED at least once in the past year and $7.5 \%$ of the patients have referred to ED more than 10 times in the past I year. In a study by Steele et al., ${ }^{[29]}$ it was found that $39 \%$ of the applicants had previously examined by a doctor. When examining 2013 and 2014 data,the number of admission to hospital was 8.2 and $8.3 /$ person, respectively. ${ }^{[30]} \mathrm{It}$ was determined that $83 \%$ of the patients who participated in this study had presented at least once and $10.5 \%$ more than 10 times to the other outpatient clinics in the past I year. It was determined that the number of hospital admission decreased with educational level and the rate of admission to outpatient clinics was higher among unemployed/retired individuals.

In the literature, there was no information on how long green tags coded patients could wait in ED. In a study by Mohsin et al..$^{[3]]}$ with the patients who have left the ED without being evaluated by any medical officer, the most important reason was found as long waiting times. There are also studies in which there is no statistically significant relationship between total waiting time and overall satisfaction. ${ }^{[32]}$ Aydın et al. ${ }^{[33]}$ examined the time elapsed until patients are first evaluated by ED assistants and found that $76.4 \%$ of the patients were evaluated within the first $5 \mathrm{~min}$. In our study, about three-fourths of the patients 
said that they could wait (Table 3), thus in fact they have expressed that they were not in emergency. The development of strategies to guide these patients to the outpatient clinics provides relief in the intensity of the EDs. This is supported by the rate of the patients who agree to wait according to the triage system (74.5\%). In our study, it was found that unemployed individuals and retirees could wait until the order of examination.

Triage implementations have recently become one of the most important issues of the EDs. ${ }^{[33]}$ Studies have shown that a regularly functioning triage system to be established can reduce the intensity of EDs and improve patient care quality. ${ }^{[17]}$ From the answers we received from the participating patients with different questions, it was determined that $74.5 \%$ of the patients claimed to comply with a triage system, $50.6 \%$ thought that emergency patients had priority, and $67.5 \%$ claimed that general order rules had to be complied with. According to the studies performed, the main reasons for the use of EDs when the outpatient clinic isopen arenot to want waiting in line and failure to reach their own physicians. ${ }^{[22,33]}$ In a study by Öztürk, $60.5 \%$ of patients described their condition as urgent and $36.5 \%$ as very urgent. ${ }^{[15]}$ The fact that patients do not want to wait order in the outpatient clinics increases the number of ED admissions. ${ }^{[22,33]}$ It was determined that the most frequent reason of the patients for coming to ED when polyclinics are open was the thought of their condition as an emergency by $46.6 \%$, followed by long waiting lines in the outpatient clinics (22.1\%). Studies have demonstrated that patients refer to EDs for getting health-care service quickly and for having investigations and treatment. ${ }^{[2]}$ Patients stated that they wish the treatment process should be started as soon as possible and that they do not wish to suffer even minor pain. ${ }^{[34]}$ In our study, we found that one of the most important reasons to prefer ED over family health centers or outpatient clinics was stated by more than half of the participants as easy accessibility of ED and the procedures are fulfilled quickly and to have several applications such as injections or drip-feed by three-fourth of the patients (Table 4). The fact that there is no sanctioning practice that prevents the emergency service from arriving of non-emergency situations plays a major role in this.

\section{CONCLUSION}

It is understood that the excessive number of admissions to EDs is due to the reasons such as, to be able to be examined and treated the same day without waiting for the inappropriate use of EDs, to reach all specialist doctors at any time of day, patients to perceive the seriousness of their own situation, proximity to the hospital, having drip-feed and injections. In the light of these data, it is a necessity to develop projects that will lead patients for primarily being examined by family physicians and to reduce unnecessary admission in the EDs, and to prepare new plans for regulation of educational activities.
Ethics Committee Approval

This study approved by the Ankara Training and Research Hospital Ethics Committee (Date: 02.09.2015, Decision No: 0608).

Informed Consent

Prospective study.

Peer-review

Internally peer-reviewed.

Conflict of Interest

None declared.

\section{REFERENCES}

1. Derlet RW, Kinser D, Ray L, Hamilton B, McKenzie J. Prospective identification and triage of nonemergency patients out of an emergency department: A 5-year study. Ann Emerg Med 1995;25:215-23.

2. Ersel M, Karcıoğlu Ö, Yanturalı S, Yürüktümen A, Sever M, Tunç MA. Bir acil servisin kullanım özellikleri ve başvuran hastaların aciliyetinin hekim ve hasta açısından değerlendirilmesi. Türk Acil Tip Derg 2006;6:25-35.

3. Andrulis DP, Kellermann A, Hintz EA, Hackman BB, Weslowski VB. Emergency department and crowding in United States teaching hospitals. Ann Emerg Med 1991;20:980-6.

4. Oktay C, Cete Y, Eray O, Pekdemir M, Gunerli A. Appropriateness of emergency department visits in a Turkish university hospital. Croat Med J 2003;44:585-91.

5. Coleman P, Irons R, Nicholl J. Will alternative immediate care services redu-ce demands for non-urgent treatment at accident and emergency? Emerg Med J 2001;18:482-7.

6. Edirne T, Edirne Y, Atmaca B, Keskin S. Yüzüncü Y1l Üniversitesi Tip Fakültesi Acil Servis hastalarının özellikleri. Van Tip Derg 2008;15:107-11.

7. Gill JM, Mainous AG 3rd, Nsereko M. The effect of continuity of care on emergency department use. Arch Fam Med 2000;9:333-8.

8. Kasper JD. The importance of type of usual source of care for children's physician access and expenditures. Med Care 1987;25:386-98.

9. Gill JM. Use of hospital emergency departments for nonurgent care: A persistent problem with no easy solutions. Am J Manag Care 1999;5:1965-8.

10. Çevik C, Tekir Ö. Emergency service admission evaluation of diagnosis codes, triage and socio-demographic. Balikesir Saglik Bil Derg 2001;3:102-7.

11. Kılıçaslan İ, Bozan H, Oktay C, Göksu E. Demographic properties of patients presenting to the emergency. Türk Acil Tip Derg 2005;5:513.

12. Northington WE, Brice JH, Zou B. Use of an emergency department by nonurgent patients. Am J Emerg Med 2005;23:131-7.

13. Morrison AK, Chanmugathas R, Schapira MM, Gorelick MH, Hoffmann RG, Brousseau DC. Caregiver low health literacy and nonurgent use of the pediatric emergency department for febrile illness. Acad Pediatr 2014;14:505-9.

14. Gentile S, Vignally P, Durand AC, Gainotti S, Sambuc R, Gerbeaux P. Nonurgent patients in the emergency department? A French formula to prevent misuse. BMC Health Serv Res 2010;10:66.

15. Öztürk Y. Evaluation of knowledge and attitude about urgency of patients in emergency. Tip Araştırmaları Derg. 2014;12:20-5.

16. Sun BC, Burstin HR, Brennan TA. Predictors and outcomes of frequent emergency department users. Acad Emerg Med 2003;10:3208. 
17. Tsai JC, Liang YW, Pearson WS. Utilization of emergency department in patients with nonurgent medical problems: Patient preference and emergency department convenience. J Formos Med Assoc 2010;109:533-42.

18. Afilalo J, Marinovich A, Afilalo M, Colacone A, Léger R, Unger B, et al. Nonurgent emergency department patient characteristics and barriers to primary care. Acad Emerg Med 2004;11:1302-10.

19. Weisz D, Gusmano MK, Wong G, Trombley J. Emergency department use: A reflection of poor primary care access? Am J Manag Care 2015;21:e152-60.

20. Philips H, Remmen R, Paepe PD, Buylaert W, Royen PV. Out of hours care: A profile analysis of patients attending the emergency department and the general practitioner on call. BMC Fam Pract 2010;11:88.

21. Çetinkaya F, Baykan Z, Naçar M. Adults perspective about family medicine and the status of service utilization TAF. Prev Med Bull 2013;12:417-24.

22. Niska R, Bhuiya F, Xu J. National hospital ambulatory medical care survey: 2007 emergency department summary. Natl Health Stat Rep 2010;26:1-31.

23. Başol N, Çelik Y, Ayan M, Esen M, Koç İ, Savaş AY. Evaluation of admissions for injection purposes which is a cause of crowded emergency department. Gaziosmanpaşa Üniv Tip Fakült Derg 2014;6:25868.

24. Haddy R, Schmaler M, Epting R. Nonemergency emergency room use in patients with and without primary care physicians. J Fam Pract 1987;24:389-92.

25. Sempere-Selva T, Peiro S, Sendra-Pina P, Martinez-Espin C, Lopez-Aguilera I. Inappropriate use of an accident and emergency de- partment: Magnitude, associated factors, and reasons--an approach with explicit criteria. Ann Emerg Med 2001;37:568-79.

26. Alagöz UÖ, Tengilimoğlu D, Ünalan D. Kayseri İli develi İlçesínde hizmet kullanıcıların bakış açısı ile aile hekimliği sistemi. Hastane Derg 2010;12:106-13.

27. Al B, Yıldırım C, Togun İ, Zengin S, Bozkurt S, Köse A, Sohbet R. Factors that affect patient satisfaction in emergency department. JAEM 2009;8:39-44.

28. Hekim Sayısı, Hekim Başına düşen kişi sayısı ve Hekim Başına Hasta Müracaat Sayıs1; 2009-2014. Avaialble from: http://www.tuik.gov. tr/PreIstatistikTablo.do?istab_id=1612. [Last accessed on 2015 Dec 25].

29. Steele S, Anstett D, Milne WK. Rural emergency department use by CTAS IV and V patients. CJEM 2008;10:209-14.

30. T.C.Sağlık Bakanlı̆̆ı Sağlık İstatistikleri Yıllığı. Available from: http://www.saglik.gov.tr/TR/belge/1-44263/saglik-istatistikleri-yilligi-2014.html. [Last accessed on 2016 Jan 15].

31. Mohsin M, Forero R, Ieraci S, Bauman AE, Young L, Santiano N. A population follow-up study of patients who left an emergency department without being seen by a medical. Emerg Med J 2007;24:175-9.

32. Sandovski U, Salman H, Bergman M, Neiman V, Bessler H, Djaldetti M. Patient's satisfactions with the staff function in an emergency department. Eur J Emerg Med 2001;8:117-22.

33. Aydın T, Aydın ŞA, Köksal Ö, Orcan S, Turan M, Aydyn T. Uludağ üniversitesi tıp fakültesi hastanesi acil servisine başvuran hastaların özelliklerinin ve acil servis çalışmalarının değerlendirilmesi. Akad Acil Tip Derg 2010;9:163-8.

34. Gilligan P, Quin G. Full capacity protocol: An end to double standards in acute hospital care provision. Emerg Med J 2011;28:547-9.

\section{Öncelik 3 (Yeşil Alan) Kodlu Hastaların Acil Servise Başvurma Sebepleri ve Acil Servisin Yoğunluğuna Etkileri}

Amaç: Bu çalışmada acil servis (AS) veri tabanının oluşturulmasına zemin hazırlayacak bazı bilgilere ulaşılması hedeflenmiştir. Acil servisin olası yoğun saatlerinin belirlenmesi, insan gücünün planlanması için başvuruların aciliyet ve uygunluğu değerlendirilmiş; uygun olmayan başvuruların nedenleri ve zamanları saptanmış, önlenmesi konusunda alınabilecek önlemler tartışılmıştır.

Gereç ve Yöntem: Bu çalışma 02.09.20I5-3I.10.20I5 tarihleri arasında ileriye yönelik olarak yapıldı. Hastaların acil servis (yeşil alan) başvurularını değerlendirmek amacıyla demografik veri $(7$ soru) ve AS başvuru nedeninin tespiti için (I5 soru) toplam 22 adet kapalı uçlu soru soruldu.

Bulgular: Hastaların yaş ortancası 37 yıldı ve \%5I.2'si erkekti. Hastalar çoğunlukla ilköğretim (\%34.3) mezunuydu. Hastaların çoğunun her hangi bir işte çalıştıkları (\%53.8) ve daha çok işçi/hizmetli (\%32.0) sınıfında çalışıkları belirlendi. Hastaların \%88. I'inin sosyal güvencesi vardı. Hastaların sıklıkla 17:00-08:00 saatleri arasında AS'ye başvurduğu görüldü (\%52.4). Hastaların \%74.7'si aile hekimini tanıyordu, \%74.4'ü aile hekimine muayene amaçlı başvurmuş ve \%48.2'si de daha önce II2'yi arayıp ambulans ile hastaneye nakli sağlanmıştı. Hastaların \%70.2'si mesai saatleri içinde aile hekimine başvurmama nedenini başta kendilerini acil hissetmeleri ve daha detaylı muayene olmak isteği (\%36.3) olarak ifade etmektedirler. Hastaların AS'yi tercih etme nedeninin başında yakınlık (\%36.5) gelmekteydi. Son bir yıl içinde hastaların tamamının AS'ye bundan önce en az bir kez başvurduğu; \%83'ünün en az bir polikliniğe başvurduğu saptandı. Hastaların çoğu (\%3।.0) sıra bitene kadar bekleyeceğini belirtti. Hastaların \%74.5'i triaj sistemine, \%50.6'sı acil hastanın öncelikli olduğu düşüncesine, \%67.5'i ise genel sıra kurallarına uyulması gerektiğini savundu. Mesai sonrası gelen hastalar AS'yi en sık tercih etme sebeplerinin yeni hastalanma (\%6I.6) olduğunu belirtti. Hastaların poliklinikler açık iken AS'ye gelmelerinin en sık sebebi ise hastanın kendisinin acil olduğunu düşünmesi (\%46.6) olarak saptandı.

Sonuç: Sonuç olarak, kişilere verilecek eğitim, acil servislerden acil olmayan işlemlerin kaldırılması (enjeksiyon, pansuman vs), aile sağlı̆ı merkezlerinin uygun yerlere yerleştirilmesi ve bu merkezlerdeki hekime olan güveninin artırılması, yeşil alan hastalarından alınan muayene katkı payı ücretlerinin yükseltilmesi ile acil servis'e (yeşil alan) olan başvurunun azaltılabileceği kanısındayız.

Anahtar Sözcükler: Acil servis; acil servis yoğunluğu; başvuru nedenleri; triyaj; yeşil etiket. 